\title{
Examination of the Problems of the Department of Turkish Language and Literature Students Receiving Pedagogical Formation Training
}

\author{
Faruk Polatcan \\ Correspondence: Faruk Polatcan, Sinop University, Education Faculty, Department of Turkish and Social Sciences \\ Education, Sinop, Turkey.
}

Received: August 26, 2019

Accepted: September 16, 2019 Online Published: September 19, 2019

doi:10.11114/jets.v7i10.4473

URL: https://doi.org/10.11114/jets.v7i10.4473

\begin{abstract}
The aim of this study is to investigate the problems encountered during education by the Department of Turkish Language and Literature students who receive pedagogical formation training. The case study was used as a qualitative research design, in which students' opinions were obtained by using a semi-structured interview form. 36 students voluntarily participated in the study, in which the convenience sampling method was used. The collected data were evaluated by using the content analysis method. The findings of the study show that the students consider the formation training necessary; that some of the lecturers did not fully teach the curriculum; they had problems with lighting and heating in the classroom; and they could not focus on the departmental courses due to the addition of the formation courses. In addition, students believe that pedagogical formation training should not be used for commercial purposes.
\end{abstract}

Keywords: Turkish language and literature, formation education, qualitative research, student problems

\section{Introduction}

One major quest of humanity is leaving a legacy for the future. This quest often occurs in the form of transferring culture, values, beliefs etc. to new generations through education. This education, which starts in the family during early childhood, is continued by teachers under the supervision of the state in the following years. Teachers play a very important role by fulfilling the task of raising new generations. While this task was the transfer of knowledge in the past, today it is performed as the interpretation of information. "Today, in addition to the subject matter knowledge, it is important that teachers have the pedagogical content knowledge, which includes knowledge such as how to teach the subject, how to manage the class etc." (Yildirim and Vural, 2014, p. 74).

There are four basic pillars of education, forming a system. These are curriculum, schools, students and teachers. In order for the system to be successful, all of the specified elements must perform their functions. However, teachers, as practitioners, have important duties in achieving the objectives stated in the curriculum (Demirtas and Kirbas, 2016, p. 138). In this respect, it is becoming increasingly important that the teacher acts as a practitioner that is in constant communication with the student (Nartgun, 2008, p. 48).

Teaching is a very important profession for the society as teachers shape students who are the future of societies. All the in class attitudes and behaviors of the teacher constitute a model for the students, and guide what kind of individuals they will become in the future (Bozkirli and Er, 2011, p. 458). Despite this, the policy on teacher training has not been well established since the foundation of the Turkish Republic. Instead, daily solutions were produced and a quantitatively sufficient number of teachers was appointed to serve in the schools. In the past, to train a sufficient number of teachers quickly, some training methods such as training teachers via letter correspondence or in accelerated programs (Demirtas and Kirbas, 2016, p. 138) were resorted to. Today, increasing quotas without providing the necessary physical conditions in education faculties, raises a question mark in terms of both the quality and the future employment of the teachers to be trained in these faculties (Alyilmaz, 2010, p. 741).

In spite of the quantitative improvement, the wrong and hasty approach in teacher education policy continues as in the past. With unlimited quotas, the graduates of the non-educational faculties are given pedagogical training certificates after completion of a two semester-long training that involves paid courses in various universities. In this pedagogical formation training (reffered as "PFD" hereafer), there are two elective courses as well as Introduction to Education, Principles and Methods of Teaching, Measurement and Evaluation in Education, Educational Psychology, Classroom Management, Special Teaching Methods, Teaching Technologies and Material Design, and Teaching Practice. These 
courses aim at helping teacher candidates guide the learning of their students by utilizing the basic concepts of education.

According to the 2023 Turkey's Education Vision announced on 23 October 2018, after the current pedagogical formation training is terminated, an expertise program on the teaching profession will be introduced at the easily accessible graduate level (http://2023vizyonu.meb.gov.tr/doc/2023_VIZYON_ENG.pdf). In spite of the fact that six months have passed since the announcement, there has been no new information about the system, and the trainings carried out by universities continue at full speed. The literature review reveals some studies about teaching profession-related attitudes of the students who receive PFT (Bozkirli and Er, 2011; Kartal and Afacan, 2012; Ozkan, 2012; Sengul Bircan, 2019), student opinions on the quality of the pedagogical formation program (Taneri, 2016), self-efficacy of teacher candidates related to the profession of teaching (Cocuk, Yokus and Tanriseven, 2015; Kanadli ve Karakus, 2016), motivations of teacher candidates toward the PFT (Altinkurt, Yilmaz ve Erol, 2014; Yildirim, Alpaslan ve Ulubey, 2019), and the problem of training teachers and PFT in Turkey. There is no study on the uncertainties experienced by teacher candidates during and after the learning process. The curent study, aimed to determine the problems experienced by the students in the Department of Turkish Language and Literature (reffered as "DTLL" hereafter) in the process of pedagogical formation education, based on the uncertainties. For this purpose, answers to the following questions were sought:

- Is pedagogical formation training necessary for teaching?

- What are the problems caused by the teaching staff?

- What are the problems caused by the classroom environments in which the courses are taught?

- Does the formation training have any impact on the success of the DTLL?

- What are the teacher candidates' views on ending pedagogical formation training?

\section{Method}

\section{Research Model}

This study, which was conducted to evaluate the problems experienced by the students in the DTLL during the process of PFT, was designed as a case study, which is a qualitative research design. Qualitative research can be defined as a type of research that utilizes qualitative data collection methods such as observation, interviews and document analysis, during which a qualitative process is followed for presenting perceptions and events in their natural environment in an integrated and realistic way (Yildirim and Simsek, 2013, p. 45). A case study is a unique study that examines a person, event or institution in depth and longitudinally, rather than conducting experimental studies in which the findings are obtained through complex statistical analyses (Paker, 2015, p. 119).

\section{Study Group}

The research was carried out with teacher candidates in the DTLL, who received PFT at Bursa Uludag University during the fall semester of 2018-2019 academic year. A total of 35 volunteer teacher candidates, $20(65 \%)$ females and $15(35 \%)$ males, participated in the study. The sample was determined by the convenience sampling method. In the conveience sampling, the researcher select the individuals and groups, from whom the data can be collected easily (Sonmez and Alacapinar, 2014, p. 142).

\section{Data Collection Tools}

The semi-structured interview form developed by the researcher was used to collect the data. When using a semi-structured interview form, the researcher prepares the interview questions in advance; however, the researcher also allows for the re-organization and discussion of the questions, by providing partial flexibility to the participants during the interview (Ekiz, 2015, p. 63).

While preparing the interview form, the literature (Kartak and Afacan, 2013; Er, 2018; Ozkan, 2012; Yildirim and Vural, 2014) was reviewed first. The obtained form was revised in light of the suggestions made by a faculty member from the DTLL in Bursa Uludağ University, and two faculty members from the DTLL in Kafkas University. To ensure the language validity of the interview form, pre-interviews were conducted with five teacher candidates who were receiving PFT. The interview form was finalized in accordance with the suggestions of teacher candidates.

\section{Data Analysis}

The data collected through the interview forms were evaluated by using the content analysis method. "The fundamental process of content analysis is to bring together similar data within the framework of certain concepts and themes, and to interpret them in a manner that the reader can understand" (Yildirim and Simsek, 2013, p. 259).

The reliability of the study was calculated using the formula of Miles and Huberman (1994) [Consensus / (Consensus + 
Disagreement) $x$ 100]. The themes and codes were extracted separately by two coders. The reliability between the two encoders was calculated as 0.87 . The codes with difference in opinion were gathered under the relevant theme as a result of the exchange of ideas between the coders.

In presenting the data obtained from the interviews, the statements by the participant are given directly to fully reflect the views of the teacher candidates. When quoting the interviews, the numbers given to the teacher candidates are added to the end of the statements (e.g. T1).

\section{Findings}

The data obtained in the study are presented in tables in accordance with the research questions.

\section{Is pedagogical formation training necessary for teaching?}

Table 1. Frequency distribution of the opinions of students in the DTLL, about the necessity of PFT

\begin{tabular}{|c|c|c|c|c|c|}
\hline Necessary & $f$ & Partly Necessary & $f$ & Unnecessary & $f$ \\
\hline $\begin{array}{l}\text { There is a possibility of } \\
\text { application }\end{array}$ & 12 & $\begin{array}{l}\text { It teaches about planing and } \\
\text { programming }\end{array}$ & 1 & It is limited to a short time & 1 \\
\hline $\begin{array}{l}\text { It is a specialization } \\
\text { training }\end{array}$ & 9 & It has a short period & 1 & $\begin{array}{l}\text { It is considered as a } \\
\text { commercial gain method }\end{array}$ & 1 \\
\hline $\begin{array}{l}\text { It teaches how to transfer } \\
\text { information }\end{array}$ & 3 & $\begin{array}{l}\text { Some of the lessons are } \\
\text { waste of time }\end{array}$ & 1 & $\begin{array}{l}\text { Those who want should be } \\
\text { able to take these courses } \\
\text { during education }\end{array}$ & 1 \\
\hline $\begin{array}{l}\text { It teaches about child } \\
\text { psychology }\end{array}$ & 2 & & & & \\
\hline $\begin{array}{l}\text { It teaches educational } \\
\text { methods }\end{array}$ & 1 & & & & \\
\hline
\end{tabular}

In Table 1, teacher candidates who believe in the necessity of PFT expressed their reasons such as "there is a possibility of application" (f: 12), "it is a specialization training" (f: 9), "it teaches how to transfer information" (f: 3 ), "it teaches about child psychology" (f: 2), and "it teaches educational methods." Opinions of two of the teacher candidates who stated that PFT is necessary are given below:

Yes, I think it is necessary; but unlike the present situation, I think a more qualified and more useful program can be introduced. The reason I think it is necessary is that an education on teaching is necessary before teaching (T10).

Yes, it's necessary. Individuals participating in this program are lacking in providing information they learn because they have studied in the science and literature department. The purpose of this program is to teach how to provide information (T29).

The teacher candidates stated that PFT is partly necessary due to reasons such as "it teaches about planning and programming" (f: 1), "it has a short period" (f: 1), and "some of the lessons are waste of time" (f: 1 ). The opinions of two of the teacher candidates who expressed these views are given below.

It's partly necessary. Because the teacher candidate who will graduate from the DTLL is already adequately equipped in terms of language and literature. It is only necessary to transfer this to the student or because certain plans and programs involved in teaching can be difficult to implement. But it's also unnecessary, because teachers can improve themselves through their love of teaching, their departments, schools, students etc (T1).

It is both necessary and not. Because I think some of the lessons waste time. I think that there should only be lessons that can be used by the teacher (T26).

The teacher candidates who think that the pedagogical formation is unnecessary stated their reasons as "it is limited to a short time" (f: 1), "it is considered as a commercial gain method" (f: 1), and "those who want should be able to take these courses during education" (f: 1). Two opinions on these reasons are given below.

PFT is not necessary. Because they can be given upon request together with department courses (T31).

I do not think formation programs are necessary. I do not think that the students who have been training in the faculties of education for four years have the same teaching vision as the students who only studied for a year (T7). 
What are the problems caused by the teaching staff?

Table 2. Frequency distribution of the problems experienced by teacher candidates in the DTLL who receive PFT

\begin{tabular}{llll}
\hline Problems caused by teaching staff & $f$ & Non-problematic teaching staff & $f$ \\
\hline They don't handle topics adequately & 3 & I am not having problems & 18 \\
They don't leave the lectern & 3 & & \\
They always talk in the same tone & 2 & & \\
They act offensively & 2 & & \\
They try to satisfy their ego & 2 & \\
They don't share summary notes & 1 & \\
They drag out one-on-one dialogues & 1 & \\
They have sexist attitudes & 1 & & \\
They strictly monitor absences & 1 &
\end{tabular}

In Table 2, the teacher candidates emphasized that they experience problems with faculty members attending the course due to reasons such as "they don't handle topics adequately" (f: 3), "they don't leave the lectern" (f: 3), "they always talk in the same tone" (f: 2), "they act offensively" (f: 2), "they try to satisfy their ego" (f: 2), "they don't share summary notes" (f: 1), "they drag out one-on-one dialogues" (f: 1), "they have sexist attitudes" (f: 1), and "they strictly monitor absences" (f: 1). The opinions of two of the teacher candidates are given below.

Some of our instructors explained the topics very well. However, some of our instructors talked about everyday life rather than teaching, and they explained unnecessary things. I just entered classes to avoid being marked absent (T25).

There are some megalomaniac teachers who humiliate some of our friends by calling them "broccoli-heads". I'm glad I didn't have to take a course from that professor. If I have to take a course from him next semester, I'll drop it (T35).

Approximately half of the teacher candidates (f: 18) stated that they did not experience any problems due to the teaching staff. The statements of two teacher candidates with this opinion are as follows:

I do not have any problems related to the academic staff who teach my classes (T3).

I had no problems with any of the teachers teaching my class. Each of them has distinct knowledge and experience (T18).

What are the problems caused by the classroom environments in which the courses are taught?

Table 3. The frequency distribution related to the problems of the teacher candidates in the DTLL who take PFT, due to the classroom environments

\begin{tabular}{llccc}
\hline $\begin{array}{l}\text { Problems Caused by the Classroom } \\
\text { Environment }\end{array}$ & $\boldsymbol{f}$ & $\begin{array}{c}\text { No problems due to classroom } \\
\text { environment }\end{array}$ & $f$ \\
\hline Small classrooms & 14 & None & 9 \\
Desks & 7 & & \\
Heating & 6 & & \\
Computer and smart board & 2 & & \\
Projector & 2 & & \\
Lighting & 2 & & \\
Cleaning & 1 & & \\
Sinks & 1 & & \\
\hline
\end{tabular}

In Table 3, teacher candidates who received PFT stated that they have problems about "small classrooms "(f: 14), "desks" (f: 7), "heating" (f: 6), "computer and smart board" (f: 2), "projector" (f: 2), "lighting” (f: 2), "cleaning" (f: 1), and: "sinks"(f: 1). Opinions of two of the teacher candidates related to the problems arising from the classroom environment are given below. 
It is obvious that the classroom environment in which the lessons are taught is mediocre. If I give this example, perhaps the problem can be better understood. It annoys me every time I come to class when they tape paper instead of a plastic cover on the top of the blackboard, where the electrical cables are located (T6).

Classrooms are very crowded. That's why we do some lectures in conference rooms. And that's not very productive (T32).

Some teacher candidates (f: 9) stated that they did not have any problems with the teaching environment. Views of two of these teachers are given below.

I have no problems with the classroom environment (T28).

I have no problem with the classroom (T34).

Does the PFT have any impact on the success the students in the DTLL?

Table 4. Frequency distribution of department courses of students in the DTLL who receive PFT

\begin{tabular}{|c|c|c|c|c|c|}
\hline Positive effects & $f$ & No effect & $f$ & Negative effects & $f$ \\
\hline Self-confidence & 3 & No effect & 6 & $\begin{array}{l}\text { Failure to devote time } \\
\text { to classes }\end{array}$ & 2 \\
\hline Giving a presentation & 3 & & & $\begin{array}{l}\text { Increase in the number } \\
\text { of courses }\end{array}$ & 2 \\
\hline Using knowledge & 2 & & & $\begin{array}{l}\text { Conflict } \\
\text { courses }\end{array}$ & 1 \\
\hline Research & 1 & & & Fatigue & 1 \\
\hline Perspective & 1 & & & & \\
\hline Self-expression & 1 & & & & \\
\hline Reinforcement & 1 & & & & \\
\hline Noticing shortcomings & 1 & & & & \\
\hline Standing at the lectern & 1 & & & & \\
\hline
\end{tabular}

In Table 4, the teacher candidates in the DTLL stated that they have seen positive effects of the PFT courses regarding "gaining self-confidence" (f: 4), "gaining skills on making presentations" (f: 3 ), "using knowledge" (f: 2 ), "research" (f: 1), "providing different perspectives" (f: 1), "self-expression" (f: 1), "reinforcing knowledge" (f: 1), "helping noticing shortcomings" (f: 1), and "standing on the lectern" (f: 1). Two examples of these statements are given below.

It has positive effects. I attend to classes more often. Thanks to giving lectures and performing question and, answer method, my self-confidence has been boosted.

I do not think there are any negative effects. Its biggest positive effect is that I have overcome my fear of teaching in a crowded class (T32).

A small portion of teacher candidates have stated that pedagogical formation education had no effect. Two of these opinions are given below.

Formation education definitely has no effect on the success in the Department of Turkish Language and Literature. We already become professionally equipped about our own department in our own faculty (T30).

Formation had no effects on my department success (T10).

Teacher candidates stated that they had been experiencing problems such as "not being able to devote enough time to department courses" (f: 2), "increase in the number of courses" (f: 2), "conflict between courses" (f: 1), and "fatigue" (f: 1) due to PFT courses. Two of these opinions are given below.

The formation education I received negatively affected my success in the department. Because we already had plenty of courses. With the addition of formation courses, I have struggled even more (T15).

I do not think it has any contributions. It has negative sides if anything. These are not being able to continuously attend classes due to course conflict, attending classes tired due to the busy schedule etc. (T22). 


\section{What are the views of the teacher candidates on ending the PFT?}

Table 5. Frequency distribution of the participants' opinions about ending the PFT

\begin{tabular}{|c|c|c|c|c|c|}
\hline $\begin{array}{l}\text { It must be taken over } \\
\text { by the Ministry of } \\
\text { National Education. }\end{array}$ & $f$ & $\begin{array}{l}\text { It must be terminated } \\
\text { completely. }\end{array}$ & $f$ & $\begin{array}{l}\text { Universities must } \\
\text { continue to provide it }\end{array}$ & $f$ \\
\hline $\begin{array}{l}\text { It must be made } \\
\text { productive }\end{array}$ & 6 & $\begin{array}{l}\text { Courses must be given within } \\
\text { undergraduate study. }\end{array}$ & 4 & $\begin{array}{l}\text { The new system is } \\
\text { ambiguous. }\end{array}$ & 2 \\
\hline $\begin{array}{l}\text { Money should not be } \\
\text { wasted }\end{array}$ & 2 & $\begin{array}{l}\text { Those with higher scores } \\
\text { must be assigned. }\end{array}$ & 1 & $\begin{array}{l}\text { It would cause factions } \\
\text { among teachers. }\end{array}$ & 1 \\
\hline $\begin{array}{l}\text { Cooperation of education } \\
\text { faculties must be } \\
\text { provided. }\end{array}$ & 2 & $\begin{array}{l}\text { Only those with a certificate } \\
\text { should be assigned for a } \\
\text { while. }\end{array}$ & 1 & $\begin{array}{l}\begin{array}{l}\text { Education would be } \\
\text { meaningless after the } \\
\text { assignments are made. }\end{array}\end{array}$ & 1 \\
\hline It's free. & 2 & & & $\begin{array}{l}\text { It would be unfair to those } \\
\text { who received a certificate. }\end{array}$ & 1 \\
\hline $\begin{array}{l}\text { It is harming those who } \\
\text { will not be assigned. }\end{array}$ & 1 & & & Job opportunity & 1 \\
\hline It would save time. & 1 & & & & \\
\hline
\end{tabular}

In Table 5, teacher candidates in the DTLL believe that this formation training must be terminate, as it was announced in the "2023 Education Vision" document by the Ministry of National Education, for the reasons such as "education must be made more productive" (f: 6), "money should not be wasted" (f: 2 ), "it would be free" (f: 2 ), "it is harming those who will not be assigned" (f: 1), "it would save time" (f: 1). Opinions of two of the teacher candidates are given below.

Changing the system can be better for raising productivity. Maybe this method would be more application-oriented. So that we can overcome our public speech fear. I did not have the courage to tell something, get in front of the board, and read aloud. Our understanding can be improved in the new system with intensive teaching and postgraduate programs.

\section{I think we would be economically and psychologically relieved if the formation training is given after thejob appointment (T28).}

Some teacher candidates who receive PFT stated that pedagogical formation must be completely terminated on the basis of reasons such as "courses must be given within undergraduate study" (f: 4), "those with high scores must be assigned" (f: 1), and "only those with a certificate should be assigned for a while" (f: 1). Statement from one of the teacher candidates is as follows:

\section{I think the new system will be more effective, didactic and useful (T4).}

Some teacher candidates receiving PFT stated the existing system must be continued on the grounds such as "the new system is ambiguous" (f: 2), "it might cause factions among teachers" (f: 1), "no point of education after the assignment is made" (f: 1), "it would be unfair to those who received a certificate" (f: 1), and "job opportunity" (f: 1) Opinions of two of the teacher candidates are as follows:

\section{I do not think it is healthy. I think they separate teachers among themselves (T5). \\ It is absurd to provide formation education to someone who is already assigned (T25).}

\section{Conclusion and Discussion}

A semi structured interview form was used in this study to examine the problems experienced during education by students in the DTLL who receive PFT. The results obtained on the basis of the five research questions in the interview form are given below.

It became clear that most of the students in the DTLL deem pedagogical formation training necessary. Students who receive this education stated that PFT is necessary because it gives an opportunity to practice teaching and enhances expertise. Alongside field-specific knowledge, pedagogical content knowledge is one of the fundamental qualiti fications required by the teaching profession. As well as being proficient in their subject areas, teachers should have qualities such as communicating well with students, being a role model, and sharing professional experience (Taneri, 2016, p. 1008). Few students who did not deem pedagogical formation necessary, stated that they feel uncomfortable 
with PFT' separation from its real purpose and its use as a means of commercial gain. In addition, the short period allocate for the training raises doubts about its quality. Supporting the study results, Kiraz and Dursun (2015, p. 1021) state that students who receive PFT complain about the limited time, the training being removed from its purpose, and commercialization.

While approximately half of students who receive PFT did not encounter any problems with the instructors, the other half stated that they feel uncomfortable due to subjects specified in the curriculum not being handled properly and instructors constantly reading on the lectern in a low voice. About the tone of voice while talking to an audience, Girgin (2010, p. 29) observed that "The most appropriate tone of voice for a lecturer would be a tone that is not monotonous and can fluctuate when needed. An extremely high or low tone of voice would disturb the audience." The results of the present study support Girgin's (2010) views.

A majority of students in the DTLL stated that the classroom environment of the PFT was too small, and that there were problems such as heating, lighting etc. in the classrooms. It is an undeniable that factors such as the number of students, desk setting, noise, cleanliness, light's direction, lighting, heating etc. play a direct role on the failure of students.

Most of students in the DTLL who receive PFT were observed to be successful in the department courses regarding self-confidence, ability to make presentations, using knowledge etc., thanks to the formation training. In accordance with the study results; Bal (2017) and Yildirim, Alpaslan and Ulubey (2019) determined that students who receive formation training have a more positive perception of self-efficacy about teaching. It was determined that prospective teachers could develop positive attitudes in their fields through PFT (Demircioglu and Kantekin, 2019).

It is clear that a small group of students cannot devote sufficient time to their departmental courses due to high number of courses they take, and that they constantly feel tired due to their busy schedule. For these reasons, it has been determined that prospective teachers who have received formation education neglect all the gains related to information literacy (Bas and Ucuzsatar, 2019). It has been detected that a very small number of prospective teachers can meet the standards of information literacy (Zan, 2019).

Students in the DTLL who receive PFT have a split in opinion between the continuation of education as it is and having it performed by the Ministry of National Education. While some of them want the traininig to be made free and offered by the MoNE after they are appointed as teacher, some others think the existing system should be continued due to the uncertainty of the new system. On the other hand, academicians who provide PFT emphasized the necessity to ensure that the education should be absorbed through spreading it to the whole university education process in cooperation with the Ministry of National Education (Kurnazoglu Atmaca, 2019).

The following suggestions can be made in the light of thefindings:

Students are prejudiced about the changes to be made in the PFT since they think that these cahnges will negatively affect them. Therefore, the details of changes to be made to the PFT system must first be shared with the stakeholders. The new regulations must be implemented only after the required discussion has been held. By addressing the preconceptions of students and society towards the cahnges to be made, the objective of the PFT can be achieved with less effort.

The PFT is given as an intensive program, only during the last year of the undergraduate teacher education or after graduation. Teacher education students and undergraudate students in other departments can take the requisite courses together by extending them over a longer period of time, which would make PFT more efficient. In addition, students can develop a positive attitude toward the teaching profession by being informed about the activities in the faculty of education.

In the studies, it has been determined that prospective teachers who have received PFT are insufficient in terms of information literacy. The fact that teachers who take on the task of raising future generations have such a problem raises concern for the future of society. Therefore, the main areas should be determined by giving up the total score approach. Candidates who pass the minimum score threshold in these fields should be eligible for appointment.

Alteration decisions regarding pedagogical formation are continuously taken. The methods tried in a short time are re-applied. The alterations are related to the form of education rather than raising teachers' qualifications. Therefore, the changes cannot satisfy prospective teachers and academicians who are stakeholders of education. Instead, in accordance with the requirements of the age, in the light of scientific data, PFT should be given along with other courses for 4 years. 


\section{References}

Altinkurt, Y., Yilmaz, K., \& Erol, E. (2014). Pedagogic formation program students' motivations for teaching profession. Trakya University Journal of Education, 4(1), 48-62.

Alyilmaz, C. (2010). Problems of Turkish teaching. Turkish Studies, 5(3), 728-749. https://doi.org/10.7827/TurkishStudies.1629

Bal, A. P. (2017). The effect of pedagogic formation training on vocational attitudes of mathematics teacher candidates. International Journal of Social Sciences and Education Research, 3(1), 58-69. https://doi.org/10.24289/ijsser.283587

Bas, B., \& Ucuzsatar, N. (2019). Selection and compliance of learning outcome of pre-service Turkish language and literature teachers in activity development process. Journal of Mother Tongue Education, 7(3), 751-764. https://doi.org/10.16916/aded.588195

Bozkirli, K. Ç., \& Er, O. (2011). The examination of Turkish / Turkish language and literature teacher candıdates' attıtudes toward teacher profession according to various variables (Kafkas University sample). Turkish Studies, 6(4), 457-466. https://doi.org/10.7827/TurkishStudies.2826

Cocuk H. E., Yokus, G., \& Tanriseven, I. (2015). Pedagogical formation students' self-efficacy and metaforic perceptions related to teaching profession. Mustafa Kemal University Journal of Social Sciences Institute, 12(32), 373-387.

Demircioğlu, E., \& Kantekin, S. (2019). Examination of history pedagogy programme students' beliefs about the concept of history through metaphor analysis. Journal of History Culture and Art Research, 8(1), 332-346. https://doi.org/10.7596/taksad.v8i1.1790

Demirtas, H., \& Kirbac, M. (2016). The views of pedagogic formation certificate program students regarding pedagogic formation training. Trakya University Journal of Education, 6(2), 138-152.

Ekiz, D. (2015). Scientific research method (4th ed.). Ankara, Turkey: Ani Publishing.

Er, O. (2018). Evaluation of the problems of formation training of Turkish language and literature within the framework of students' opinions. International Learning Teaching and Educational Research Congess, 6-8 Sptember 2018, Amasya, Turkey.

Girgin, A. (2010). Speaking method. Marmara University Faculty of Communication, 16, $21-32$. http://2023vizyonu.meb.gov.tr/doc/2023_VIZYON_ENG.pdf (Taken on May 4, 2019).

Kanadli, S., \& Karakus, F. (2016). The effect of pedagogical formation certificate program on prospective teachers' professional self-efficacy and attitudes: a mixed-method study. Journal of Human Sciences, 13(3), 3807-3826. https://doi.org/10.14687/jhs.v13i3.3852

Kartal, T., \& Afacan, O. (2012). Examining attitudes of prospective teachers who took pedagogical formation education towards teaching profession. Mehmet Akif Ersoy University Journal of the Faculty of Education, 12(24), 76-96.

Kiraz, Z., \& Dursun, F. (2015). The perceptions of teacher candidates regarding the pedagogical formation training they receive. Mersin University Journal of the Faculty of Education, 11(3), 1008-1028. https://doi.org/10.17860/efd.37544

Korkmaz, A., (2003). Classroom organization. Leyla Kuçukahmet (Ed.). Classroom management (pp. 268-287). Ankara: Nobel Academic Publishing.

Kurnazoglu, A. F. I. (2019). Determination of the competence of pedagogical formation training students and opinions of academicians about pedagogical formation training certificate programme. (Unpublished Master's Thesis). Balıkesir University Institute of Social Sciences, Balikesir, Turkey.

Miles, M. B., \& Huberman, M. A. (1994). Qualitative data analysis. London, United Kingdom: Sage Publication.

Nartgun, S. S. (2008). Candidate teachers' views on the criteria of appontment to ministry of national education institutions. Abant Izzet Baysal University Journal of Faculty of Education, 8(2), 47-58.

Ozkan, H. H. (2012). Investigation of pre-service teachers' attitudes towards teaching profession in a teaching formation certification program (SDU sample). Ahi Evran University Journal of Faculty of Education, 13(2), 29-48.

Paker, T. (2015). Case study. Fatma Nevra Seggie ve Yasemin Bayyurt (Ed.). Qualitative research methods, techniques, analysis and approaches (pp. 119-134). Ankara, Turkey: Ani Publishing.

Sengul, B. T. (2019). Attitudes of history teacher candidates who took pedagogical formation education towards 
teaching profession. Kastamonu Education Journal, 27(2), 589-598.

Sonmez, V., \& Alacapinar, F. G. (2014). Sampled scientific research methods. (3rd ed.). Ani Publishing.

Taneri, P. O. (2016). Opinions of prospective teachers about the quality of pedagogical formation certificate program (Çankiri sample). Kastamonu Education Journal, 24(3), 997-1014.

Yildirim, A., \& Simsek, H. (2013). Qualitative research methods in the social sciences. (9rd ed.). Ankara, Turkey: Seçkin Publishing.

Yildirim, I., \& Vural, O. F. (2014). Problems related with teacher training and pedagogical formation in Turkey. Journal of Teacher Education and Educators, 3(1), 73-90.

Yildirim, K., Alpaslan, M. M., \& Ulubey, O. Y. (2019). Exploring teaching motivation of preservice teachers studying at pedagogic formation program. Abant Izzet Baysal University Journal of Faculty of Education, 19(1), 428-439. https://doi.org/10.17240/aibuefd.2019.19.43815-455882

Zan, B. U. (2019). Infornation literacy views of the teacher candidates registered to pedagogical formation certificate program on. International journal of human sciences, 16(1), 249-269. https://doi.org/10.14687/jhs.v16i1.5549

\section{Copyrights}

Copyright for this article is retained by the author(s), with first publication rights granted to the journal.

This is an open-access article distributed under the terms and conditions of the Creative Commons Attribution license which permits unrestricted use, distribution, and reproduction in any medium, provided the original work is properly cited. 